\title{
Erratum to: Focused Issue on Indigenous Management Research
}

\author{
Dirk Holtbrügge
}

\section{Erratum to: Manag Int Rev DOI 10.1007/s11575-012-0160-1}

The Focused Issue on Indigenous Management Research is guest-edited by Dirk Holtbrügge, K. Narayanan, and Wang Hui.

Yet, the guest editor's introduction is authored by Dirk Holtbrügge alone.

MIR's editorial office and Dirk Holtbrügge regret that not all guest editors' names are printed on the issue's cover.

\section{Published online: 24.04 .2013}

(c) Springer-Verlag Berlin Heidelberg 2013

The online version of the original article can be found under doi:http://dx.doi.org/10.1007/s11575-012-0160-1

Prof. D. Holtbrügge $(\bowtie)$

Department of International Management, University of Erlangen-Nürnberg, Nürnberg, Germany e-mail: dirk.holtbruegge@wiso.uni-erlangen.de 